\title{
Bioactive Hierarchical Structures for Genetic Control of Bone Morphogenesis
}

\author{
Pilar Sepulveda*, Larry L. Hench \\ Centre for Tissue Engineering and Repair, Department of Materials, \\ Imperial College of Science, Technology and Medicine, \\ Prince Consort Road, London SW7 2BP, UK
}

Received: September 27, 2001; Revised: July 10, 2002

\begin{abstract}
For thirty years it has been known that certain compositions of $\mathrm{Na}_{2} \mathrm{O}-\mathrm{CaO}-\mathrm{P}_{2} \mathrm{O}_{5}-\mathrm{SiO}_{2}$ glasses will form a mechanically strong, chemical bond to bone. These materials have become known as bioactive glasses and the process of bonding is called bioactive fixation. Bioactive glasses are widely used clinically in the repair of bone defects. Recent research at the Imperial College Tissue Engineering Centre has now established that there is a genetic control of the cellular response to bioactive materials. Seven families of genes are up-regulated when primary human osteoblasts are exposed to the ionic dissolution products of bioactive glasses. The gene expression occurs very rapidly, within two days, and includes enhanced expression of cell cycle regulators. The consequence is rapid differentiation of the osteoblasts into a mature phenotype and formation of large three-dimensional bone nodules within six days in vitro. These cell culture results correlate with extensive human clinical results using the same bioactive material. The new genetic theory of bioactive materials provides a scientific foundation for molecular design of new generation of resorbable bioactive materials for tissue engineering and in situ tissue regeneration and repair. Application of this theory to the synthesis of bioactive foams for tissue engineering of bone is described.
\end{abstract}

Keywords: bioactive, foams, sol-gel, genes, bone, porous, tissue engineering

\section{Introduction}

The clinical success of bioactive glasses in treatment of periodontal disease ${ }^{1}$, facial bone augmentation ${ }^{2}$, and middle ear devices ${ }^{3}$, has stimulated a large number of research works in the field of tissue regeneration. In vivo studies have also confirmed the higher bone regenerative potential of bioactive glasses, compared to glass ceramics and hydroxyapatite $^{4}$. Bioactive glasses have the ability to bond to soft connective tissues as well as bone ${ }^{5}$. Many materials can be bioactive with variable rates of bonding to tissue, including a wide range of melt-derived and sol-gel derived glasses in compositions within the $\mathrm{Na}_{2} \mathrm{O}-\mathrm{CaO}-\mathrm{P}_{2} \mathrm{O}_{5}-\mathrm{SiO}_{2}$ system ${ }^{5}$, solgel derived silica, titania ${ }^{7}$ and to a lesser degree, hydroxyapatite ceramics ${ }^{8}$.

The ability to bond to hard and soft tissues has been described to be the result of interfacial reactions, that start with the ionic exchange on the glass surface that creates a hydrated layer of $\mathrm{Si}-\mathrm{OH}$. The silanols undergo polycondensation to form a silica gel layer of high surface area. The gel layer provides a large number of sites for precipitation of calcium and phosphate that are dissolved in the surrounding medium, with nucleation and crystallisation of amorphous calcium-phosphate (HCA layer) ${ }^{5}$. Because of the highly porous texture of sol-gel materials, they exhibit greater bioactivity in vitro and have expanded the compositional range of bioactive glasses ${ }^{6}$.

Recent research at the Imperial College Tissue Engineering Centre has now established that there is a genetic control of the cellular response to these bioactive glasses. This was demonstrated by Xynos et al. in experiments involving the exposure of human primary osteoblasts to the soluble chemical extracts of 45S5 Bioglass ${ }^{\circledR 9-11}$. Xynos et

*e-mail: pilar.sepulveda@epsrc.ac.uk

Currently at: Instituto de Pesquisas Energéticas e Nucleares, IPEN/CNEN C.P. 11049, 05542-970 São Paulo - SP, Brazil 
al. reported that the ionic products of the glass dissolution affected the gene-expression profile causing up-regulation of seven families of genes including cell cycle regulators, growth related gene and apoptosis regulators ${ }^{10}$. Expression of a potent osteoblast mitogenic growth factor, insulin-like growth factor II (IGF-II), was increased to $290 \%{ }^{11}$. The genetic stimuli exerts direct control over cell cycle regulation causing the rapid differentiation of osteoblasts into a mature phenotype, proliferation and formation of large threedimensional bone nodules. Osteoblast proliferation with bioactive glass extract was to $155 \%$ of control. These cell culture results correlate with extensive human clinical results using 45S5 glass.

This work describes the process for making macroporous sol-gel derived bioactive glasses, termed bioactive foams, and characterization for physical structure. The glasses can be manufactured with specific architectures to obtain controlled rates of glass resorption and rates of chemical dissolution of species that promote tissue regeneration, creating a novel three-dimensional tissue construct similar to natural tissues.

\section{Methods}

A novel process was developed through a combination of previous knowledge on foaming ${ }^{12}$ applied to the sol-gel technology typically used to manufacture bioactive glass powders and monoliths for bone repair. A detailed description of the process is given reference by the same authors ${ }^{13}$. The steps for sol-gel foam manufacture are represented in Fig. 1. The procedure was applied to systems of various complexities, including the unary pure silica (100S), the binary $70 \% \mathrm{SiO}_{2}-30 \% \mathrm{CaO}(70 \mathrm{~S} 30 \mathrm{C})^{14}$, and the ternary $60 \% \mathrm{SiO}_{2}, 36 \% \mathrm{CaO}, 4 \% \mathrm{P}_{2} \mathrm{O}_{5}(58 \mathrm{~S})^{15}$, in molar percentage. Physical characterization of the porous foams consisted of microstructural observation, pore size and textural analysis. Scanning electron microscopy (JEOL, JSM T220A) on gold-coated specimens was used to examine the morphological and textural features of the foams. Larger pore size ranges were assessed by intrusion mercury porosimetry (PoreMaster 33, Quantachrome). The specific surface area and the porosity in the framework were determined by nitrogen adsorption technique (Autosorb AS6, QuantaChrome).

\section{Results and Discussions}

Flawless foamed glasses were successfully produced with various compositions in a wide range of shapes and sizes. The foams exhibit a 3D hierarchical structure of an interconnected macropore network in a bioactive glass matrix containing mesopores (Fig. 2). Macropores appear in broad distributions with diameters in the range of $10-200 \mu \mathrm{m}$, as seen by mercury porosimetry (Fig. 3a).

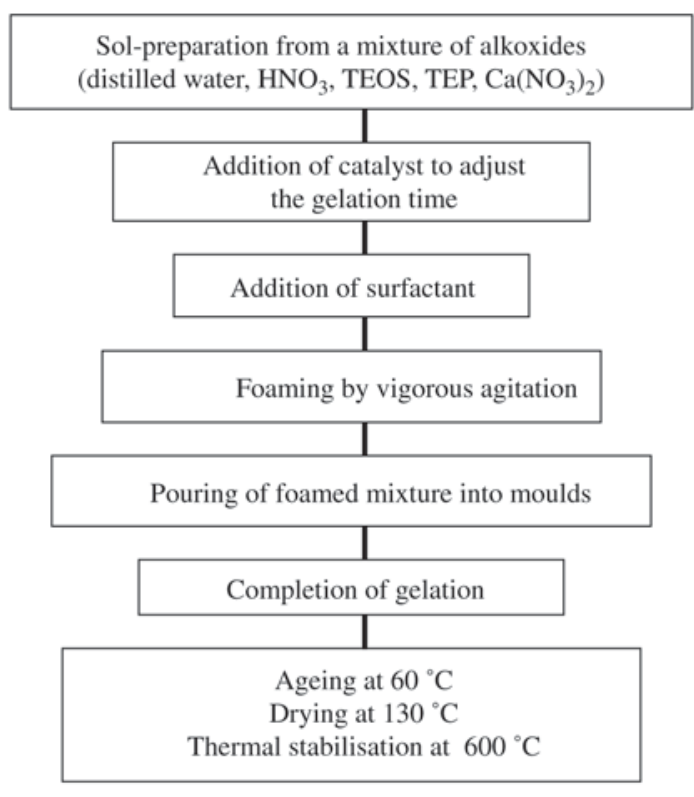

Figure 1. Schematic representation of the manufacture of bioactive foams.

Larger pores were noted under SEM obseravtion, in the range of $500 \mu \mathrm{m}$. The pore size range and interconnectivity of macropores significantly depends on the amount of foam produced. The mesoporous texture of the foam walls is typical of sol-gel glasses. Nitrogen sorption analysis of the solgel foams revealed surface areas in the range of $106-283 \mathrm{~m}^{2} / \mathrm{g}$ and average mesopore size in the range of $10-28 \mathrm{~nm}$, as seen in Fig. 3b. Although foaming leads to a slight textural variation, a small shift in pore size distribution towards larger sizes is noticed. This effect is more significant in the three-component system due to its greater complexity in condensation ${ }^{16}$.

The manufacture of hierarchical structure using bioactive compositions creates a number of advantages. The main potential application for these materials involves repair and reconstruction of damaged tissue. This is the main aim of tissue engineering, the multi-disciplinary science that develops new natural tissues from isolated cells for repair and functional regeneration of failed organs or parts of tissues damaged due to diseases, trauma and tumours ${ }^{17}$. Scaffolding constructs with specific porous architectures are used to support organisation and formation of 3D differentiated tissue, given that conventional monolayer cell cultures are unable to produce this effect. These constructs are impregnated with specific cells and growth factors that can trigger certain types of cell differentiation cascade resulting in rapid tissue formation. Cells are obtained from the patient in biopsies or clinical interventions and are seeded on the substrates, then cultured in vitro for varied periods of time 

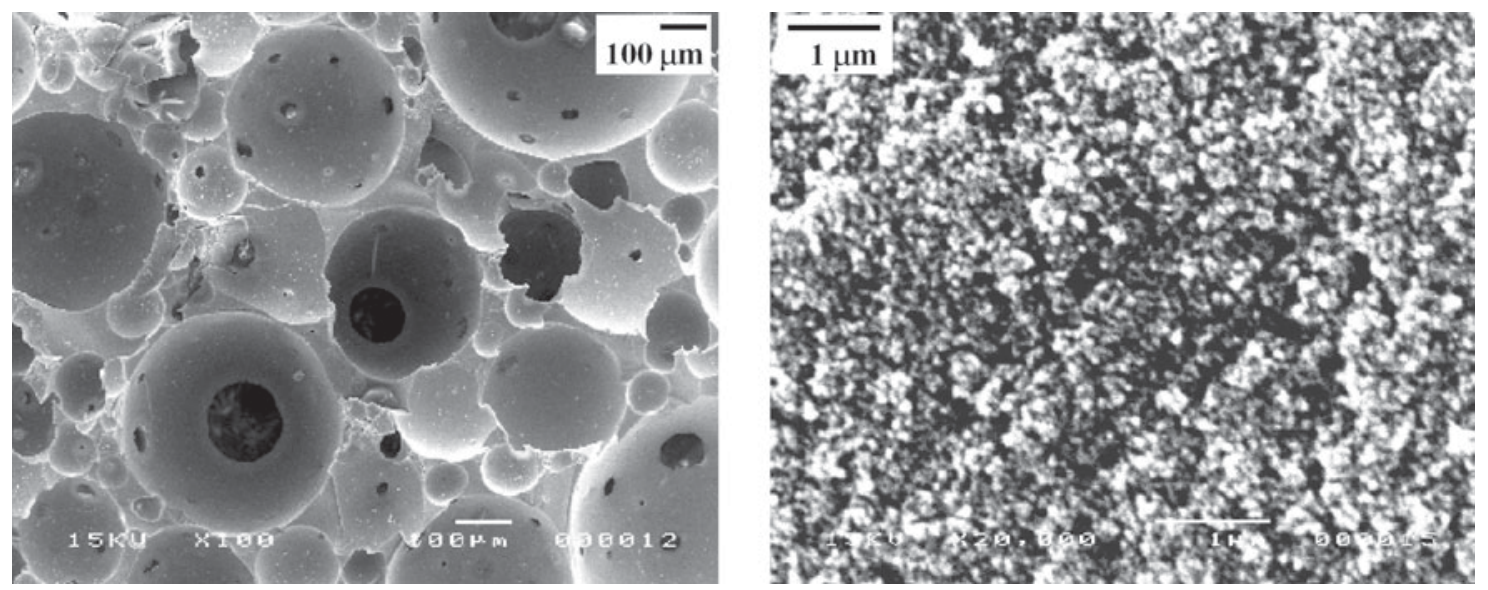

Figure 2. Bioactive foam structure observed under scanning electron microscopy: a) macroporous network and b) mesoporous matrix.
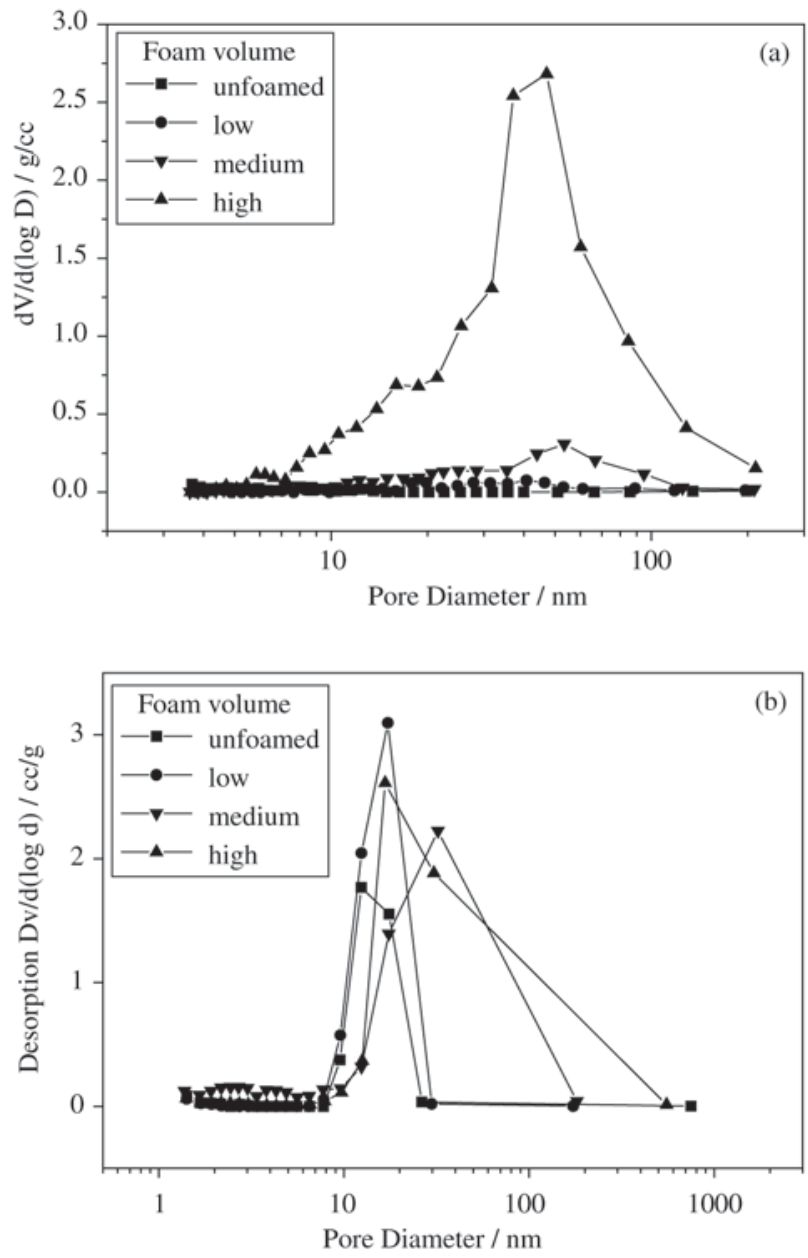

Figure 3. Typical pore size distribution of bioactive foams (70S30C) produced by foaming of sol-gels showing two main pore size ranges determined by a) mercury porosimetry and b) nitrogen sorption. Unfoamed specimens and specimens produced from sols foamed up to various volumes are shown. or immediately re-implanted.

The bioactive foams combine many of the requirements for use as tissue engineering scaffolds. Mesoporosity supplies the high surface area, sites for cells to attach and adsorption of chemical substances, while the intricate framework and open macropores can potentially support 3D organisation of cells and tissue ingrowth. Bioactive compositions supply a combination of ions that provide biological stimuli to enhance cellular differentiation and proliferation via gene activation and the ability of tissue bonding. The glasses can be produced in resorbable compositions and desired pore size range to dissolve at controlled rates and match those of tissue growth, creating a novel three-dimensional tissue similar to natural tissues and organs.

The new genetic theory of bioactive materials provides a scientific foundation for molecular design of new generation of resorbable bioactive materials for tissue engineering and in situ tissue regeneration and repair.

\section{Conclusions}

Discovery of a novel technology that comprises foaming of sol-gel systems has made possible the manufacture of scaffolds for tissue engineering. The bioactive foam structure is characterized by a three-dimensional array of open pores enclosed in a mesoporous matrix that is typical of sol-gel materials. This combination of properties places the bioactive foams into a new class of bioactive materials with the potential of supporting tissue proliferation as well as providing the biological stimuli to enhance cell growth and differentiation, and resorb by controlled rates creating a novel three-dimensional tissue similar to natural tissues and organs.

\section{Acknowledgements}

The main author is indebted to FAPESP (Grant number 
99/02172-4) for providing funding to conduct this research at the Imperial College. The authors also thank the support of the U.K. Engineering and Physics Research Council for the financial support.

\section{References}

1. Wilson, J.; Low, S.; Fetner, A.; Hench, L.L. Bioactive materials or periodontal applications, in Biomaterials in Clinical Applications, Eds. A. Pizzoferrato, P.G. Marchetti, A. Ravagliogli, A.J.C. Lee, Elsevier, Amsterdam, p. 223, 1987.

2. Wilson, J.; Mervin, G.E. Biomaterials for facial bone augmentation: comparative studies, J. Biomed. Mater. Res., v. 22, n. A2, p. 159, 1988.

3. Mervin, G.E.; Wilson, J.; Hench, L.L. Current status of the development of Bioglass ${ }^{\circledR}$ ossicular replacement implants, in Biomaterials in Otology, Ed. J.J. Grote, M. Nijhoff, The Hague, 220, 1984.

4. Oonishi, H.; Hench, L.L.; Wilson, J.; Sugihara, F.; Tsuji, E.; Matsuura, M.; Kin, S.; Yamamoto, T.; Mizokawa, S. Quantitative comparison of bone growth behavior in granules of Bioglass ${ }^{\circledR}, \mathrm{A}-\mathrm{W}$ glass-ceramic, and hydroxyapatite, J. Biomed. Mater. Res., v. 51, p.37-46, 2000.

5. Hench, L.L. Bioceramics: From concept to clinic, J. Am. Ceram. Soc., v. 74, n. 7, p.1487-510, 1991.

6. Sepulveda, P.; Jones, J.R.; Hench, L.L. In vitro dissolution of melt-derived 45S5 and sol-gel-derived 58S Bioglass $^{\circledR}$. Submitted to the Journal of Biomedical Materials Research.

7. Li, P.J.; Ohtsuki, C.; Kokubo, T.; Nakanishi, K.; Soga, N.; DeGroot, K. The role of hydrated silica, titania, and alumina in inducing apatite on implants, J. Biomed. Mater. Res., v. 28, n. 1, p. 7-15, 1994.

8. Le Geros, R.Z. Dense Hydroxyapatite, in Introduction to ceramics. Eds. L.L. Hench, J. Wilson, Singapore: World Scientific; 1993.
9. Xynos, I.D.; Hukkanen, M.V.J.; Buttery, L.D.K.; Hench, L.L.; Polak, J.M. Bioglass (R) 45 S5 stimulates osteoblast turnover and enhances bone formation in vitro: Implications and applications for bone tissue engineering, Calcified Tissue Int., v. 67, n. 4, p 321-329, 2000.

10. Xynos, I.D.; Edgar, A.I.; Buttery, L.D.K.; Hench, L.L.; Polak, J.M. Gene-expression profiling of human osteoblasts following treatment with the ionic products of Bioglass ${ }^{\text {ò }} 45 \mathrm{~S} 5$ dissolution, J. Biomed. Mater. Res., v. 55, n. 2, p. 151-157 2001.

11. Xynos, I.D. Edgar, A.I.; Buttery, L.D.K.; Hench, L.L.; Polak, J.M. Ionic products of bioactive glass dissolution increase proliferation of human osteoblasts and induce insulin-like growth factor II mRNA expression and protein synthesis, Biochem. Biophys. Res. Commun., v. 276, n. 2, p. 461-465, 2000.

12. Sepulveda, P.; Binner, J.G.P. Processing of cellular ceramics by foaming and in situ polymerisation of organic monomers, J. Eur. Ceram. Soc., v. 19, n. 12, p. 20592066, 1999.

13. Sepulveda, P.; Jones, J.R.; Hench, L.L. Bioactive SolGel Foams for Tissue Repair, J. Biomed. Mat. Res., v. 59, n. 2, p. 340-348, 2002.

14. Saravanapavan, P.; Hench, L.L. Low temperature synthesis and bioactivity of gel-derived glasses in the binary $\mathrm{CaO}-\mathrm{SiO}_{2}$ system, J. Biomed. Mater. Res., v. 54, n. 4, p. 608-618, 2001.

15. Li, R.; Clark, A.E.; Hench, L.L. An investigation of bioactive glass powders by sol-gel processing, J. App. Biomat., v. 2, p. 231-239, 1991.

16. Jokinen, M.; Rahiala, H.; Rosenholm, J.B.; Peltola, T.; Kangasniemi, I. Relation between aggregation and heterogeneity of obtained structure in sol-gel derived $\mathrm{CaO}$ $\mathrm{P}_{2} \mathrm{O}_{5}-\mathrm{SiO}_{2}$, J. Sol-gel Sci. Tech., v. 12, p. 159-167, 1998.

17. Langer, R.; Vacanti, J. Tissue engineering, Science, 260, p. $920-926,1993$. 